\title{
Industrial Development:Socio-Economic Changes in Kashmir Society (1339-1551.A D.)
}

\author{
Dr. Syed Damsaz Ali Andrabi \\ College Teacher, Department of Higher Education, Jammu and Kashmir \\ damsaz.andrabi@gmail.com
}

\begin{abstract}
The establishment of Muslim rule in valley of Kashmir in, 1339.A.D.proved as a landmark in the socio-economic and religious history. The new rule attracted philosophers, scholars, artisans from different pockets of Persia and Central Asia. As they were from advanced cultural centers, on reaching Kashmir they effortlessly imparted their technical skill to the natives of valley. Not only social structure got changed, but also new centers of advancement and awareness were opened by them at different places. Their indepth knowledge attracted and influenced the people of all faiths towards the new industrial modules. Some of the arts and crafts that were then unknown in valley were for the first time introduced by them. The main reason behind the arrival of Muslim artisans was the liberal attitude provided by the rulers. All the tools of progress like education, connectivity and peace engulfed the whole of valley. The valley was turned into industrial garden and new economic avenues proved as a basic source and deciding factor of overall change in society.
\end{abstract}

Keywords: Education, Industries, Arts and Crafts, Economy ,Peace etc.

Method and Findings: No detailed and well connected research paper has been written so far on the particular subject .For the completion of paper both primary and secondary sources were consulted. Besides this other necessary tools like field survey and interaction with people linked to different skills helped a lot to know about the changes that occurred in society and ultimately reshaped the destiny of people towards new developments. With the result there was complete peace and harmony in the day today life of people.

\section{INTRODUCTION}

Kashmir is noted for its beauties and bounties. It has been for centuries the object of attention for poets, painters, reformers, artisans, scholars and philosophers. The beauties of Kashmir have also been the cause of its outside intervention in course of her history. So far as peace, development and justice are concerned Muslim rule holds great importance in the history of Kashmir valley. The only aim of rulers was to spread the message of love and unity among people without the consideration of faith and caste. With the result people at large got attracted and influenced by them. Because of the participation of people in new modules the economy of people and state underwent many great changes. The rule of Muslims in valley was established by Shah Mir in,1339.A.D, commonly known as Sultan Shamsu'd-din Shah Mir.

The hindu rule declined because of complex social structure. Majority of the people were out of the social system and were not having any access to the doors of administration. No doubt the valley was rich in resources but they were misutilized by the upper stratra of society. The valley masons were known for their architecture excellence. The same is visible while having a look on the temples of Karkota dynasty, the temples of Awantivarman and others . Among the Karkota rulers the rule of Lalitaditya, 724-61,A.D,is note of worth. His reign was really an epoch making for the people. Not only boundaries were extended but 
there was internal peace and consolidation. His liberal religious policy is yet another proof of benevolence. Besides being the follower of Lord Vishnu the number of other temples, vihars, and stupas were constructed and also villages were granted for their maintenance. Not only images of Vishnu but also the images of Lord Buddha and Grauda were foxed in a number of temples and dedicated for public worship,as the same is visible in the temple of Martnand dedicated to sun God. During the period of Utpala dynasty the stone architecture touched its heights that too under the revolutionary phase of Awantivarman, 855-83,A.D,that can be seen through two magnificent temples constructed at his capital Awantipora namely Awantiswamian temple(Vishnu temple) and Awantivishwara temple (Shiva temple). These temples probably represent the last stage of the growth of temple stone architecture in valley of Kashmir.The design of these temples is almost having the resemblance with Karkota temples. They too are made up of big stone blocks and their layout is almost the same. However a number of improvements were made in it by Utpalas, especially their pillars are more ornate and are magnificently carved that they look like wooden pillars. There is combination of Indian stone art, West Asian and Kashmiri. Because some successors of Awantivarman namely Gopalavarman,902-904.A.D,and Suravarnan-I, 933-934,A.D,have maintained very close contacts with other parts of world like, Afghanistan etc. After the Utpala rulers there was complete social unrest in society. None of the rulers were in a position to maintain grip over administration,with the result stone masonry declined completely. The complete social anarchy provided opportunity for others that ultimately led to the downfall of hindu rule and establishment of Muslim rule in valley in, 1339,A D, by Shamsu'd-din Shah Mir from Swat. The dynasty ruled over the valley for more than two hundred years. It was during their time the rigid and complex social structure was replaced by a new concept of unity and equality. During the period a number of Muslim missionary groups with Central Asian background visited Kashmir. They contributed in their own ways to enlighten the people of valley through a variety of new skills. As they were from advanced cultural centres on reaching Kashmir they effortlessly imparted technical skills and knowledge to the natives in a variety of arts and crafts. During the period a large number of art and crafts were introduced and even today Kashmir is famous all over the world.

Among the Sultanate rulers only two of them were very famous among the people without the consideration of religion. The one is Sultan Shihabu'd-din, 1389-1413.A.D,and Sultan Zainul Abidin, 1420-1470.A.D. Shihabu'd-din was not only a great conqueror but also an able administrator. He was very kind to people belonging to other faiths and every sort of facility was provided to them. Number of measures were also taken to preserve their religious places and new temples were also constructed for the people. Sultan Zainul Abidin was the most popular among all the Sultans of Kashmir. He took series of measures for the betterment of his subjects and thus earned the great name of Bud Shah. The era of Sultan Zainul Abidin is the golden period of industrial development in valley. Large number of arts and crafts which were earlier introduced during the time of Sultan Qutub'd-din, 1373-1389,A.D, by Mir Syed Ali Hamdani were boosted by Sultan Zainul Abidin.

For the promotion of arts and crafts he used novel methods. He provided every sort of patronage to the foreign artists and craftmen, due to which a large number of artists and craftsmen thronged into the valley. Above all significant progress was made in the fields such as, Shawl work, Embroidery, Silk, Carpet, Pattu, Gabba, Namdah, Paper and Book binding, Paper Machie, Wood work,Kangri work, Music, Silver and Copperware works.Before the introduction of these arts and crafts Kashmir was poor in industrial sector. No doubt some of these arts and crafts were introduced before Zainul Abidin, but really these arts and crafts developed under his proper care. The art of making Pashmina was most probably imported from Tibet for which Kashmir is still famous. The art of making bridges in the country was also the contribution of Persian artists during the time of Zainul Abidin.

\section{Shawl Industry}

During his time Kashmiri Shawl began to be exported to other parts of world. Shawl wool had considerable economic and commercial importance. Zainul Abidin made Shawl industry a flourishing industry and 
earned international reputation. There were two types of principal Shawls that were mostly manufactured by the workers, Kani Shawl and Amalikar Shawl. After his death social problems faced by the people resulted in the decline of arts. But the trade was revived by Central Asian ruler Mirza Haider Dughlat who occupied valley in, 1540-51.A D. During his short tenure there were Shia Sunni tensions in society, but still he managed to boost the Shawl trade and invited some trained masters like,Nazuq Beigh a resident of Khuqand.Nazuq Beigh is being credited that some newer designs in Shawls were introduced as the Texture of Shawl, a new element of red and green spots in regular rows. The same was unknown before his arrival. Because of new design the Shawls of Kashmir earned good market outside valley.Several types of Shawls of finished nature were then manufactured by Kashmiri Shawl workers and "Jamawar" also called as "Param-Naram" being the best among the manufactured Shawls. There seems to have more excellency in the art with the coming of Mughals in 1586.A.D.

\section{Embroidery Work}

The art was introduced in valley during the time of Sultan Qutub,d-din, 1373-89.A.D, after the arrival of Mir Syed Ali Hamdani along with large number of followers. The workers of the art have remained very closely associated with Shawl industry. Work of embroidery is done with the help of needle. Some of the main types of Embroidery are, suzane, amali, chikin duzi and jalik duzi. The art was mostly practised by the rural skilled workers and at present has become very common among the people,especially the Tila Pheran of Kashmir is very much popular among outsiders. The same is recognized as part of Kashmiri culture.

\section{Silk Industry}

Side by side with the development of Shawl industry the Silk industry also progressed too much during the rule of Sultan Zainul Abidin . The industry usually was one of the principal sources of revenue to Muslim Sultans. To boost the Silk work the best quality of cocoons were imported from Tibet by Zainul Abidin. The sericulture industry developed in Kashmir because of abundance of mulberry trees, suitable elevation and favourable climate. The Silk work was started by Sultan Zainul Abidin, boosted by Mughals,15861753.A.D, and ultimately touched its heights under the Afghans,1753-1819.A.D. Today it is the most reputed government controlled industry and means of livelihood to many people belonging to state and about four thousand people at present are working with the industry. No other industry is endowed with such facilities as the Silk industry of Kashmir.

\section{Carpet Weaving}

The industry of Carpet was introduced in valley by Sultan Zainul Abidin and flourished for a long time. The different designs of Carpets woven by Qalin Bafs(workers) and among all "Pile Carpet" attained great importance. They were having the floral designs with flowers, mosques, blossoms, trees, hills, lakes, forest, gliding fish and wild animals. All the Kashmiri styles varied as they usually rest on a dound basis. There is a great scope for the Carpet art if the traditional designs are preserved because they are identity of Kashmiri art. The artisans are locally urged to be true to their own nature. Keeping the world market intact the workers should look for improvements. Although the work is done by hand, still the industry is highly organised and all the required essentials of a large scale production. Almost twelve percent of male population in Srinagar city earn their livelihood from this very great industry. In rural areas the percentage exceeds to a larger extent. The cheaper Carpets were having the more demand as compared to expensive ones. After the death of Sultan Zainul Abidin in, 1470.A. D, the industry decayed and died, because of the non seriousness of rulers and loss of interest from the side of Qalin Bafs. Even the workers too are responsible because they have never tried to improve their art. Some efforts were later on made by Mirza Haider Dughlat, 1540-51,A.D,Emperor Jahangir, 1605-28.A.D,and Maharaja Rangit Singh to revive the work. During the regime of later the art really touched the heights, but declined very shortly,because of 
the problems faced by the workers, what they earned was taken away by rulers. They were tied with Qalin looms and were not allowed to migrate towards other areas. In such circumstances how could a worker work. So in the beginning number of people were benefited but later same proved as a source of trouble.

\section{Pattu Making}

The cloth is used in Kashmir during winter season. Rough wool in Kashmir is called "yer" and the woolen stuff called as Pattu. Because of the poverty people were not in a position to use or purchase other cloth. The said industry remained well organized during the time of Zainul Abidin. During his time the rugs of Zainagir Srinagar were having the great market value. The warm wool rugs" lois", ekbari and dohari, i. e. in one piece or two pieces, the chadar-i-khudrang and qalam-pattu were having the great demand. The art boosted the economy of people.

\section{Gabba Making}

The Gabba is a unique type of flooring used in Kashmir especially in winter season. Gabba is prepared from old woolen blankets in different designs. The popular quality and types are, Dak-guldar with a circular star in the middle know as chand resembles the moon. The industry created a new class of tradesmen in the city known as Zachagarus. They used to move from area to area to collect the old blankets and sell them to Gabba manufacturers. As Srinagar was the centre of religious activities and was easier for them to sell out their products at good prices. The work was mostly opted by rural population. The famous and best quality of Gabba is manufactured in district Anantnag of valley.

\section{Namdah Industry}

The origin of the industry is not known, but was patronized by the Zainul Abidin. The work of Namdah was mostly opted by rural population. Carpet rug industry, based upon milling up woven fabrics and then figuring them with embroideries in a most ingenious manner. They are mostly used during winters. Namdah of plain type are manufactured through a process of dyeing, designing, embroidering, washing and finally balling before it is ready to place the item in the market for sale. The locally manufactured item was having the great demand outside valley during and after the world war ii. But in modern times its consumption is very less because of the availability of carpets at cheaper prices. Now the art is at its verge of decline and very soon the art will be no more in the valley.

\section{Paper and Book Binding Industry}

To train the locals in the art of Paper making and Book binding, Sultan Zainul Abidin sent two persons out of Kashmir to Samarkand to receive the training in these arts and crafts .During their stay in Samarkand, one of them learned the art of Paper making, while the other learnt Book binding. When they returned to Kashmir they taught these arts to others. Paper making arrangement was made in Phag pargana.The artists were also bestowed with jagir as a sort of encouragement.

\section{Paper Mache}

The Kari-Qalamdani craft was introduced in Srinagar by Sultan Zainul Abidin, who invited experts from Samarkand. The art was mostly inhabited by Shia community and remained confined with them. Thus the art became hereditarial and passed from father to son. It is a peculiar art of Kashmir. The process of making Paper Machie is rather elaborate. Sheets of paper are pasted on to moulds of the required form and painted and varnished. A beautiful pattern is also done by painting with gold paint by spreading a numbers of minute branches and leaves on a white ground, a border of brighter colouring is added . Not only design on sheets are completed but sometimes figures of men and animals are introduced. The designs are of elaborate nature and drawing is of free hand. They are shown by master called as Naqash. The work is 
extended to floral decorations and illuminations. To suit the changing tastes a variety of articles such as, candle stick, tea poys and picture frames were made to make the art alive and attractive. The art of Paper Machie has already found its market in Kabul Afghanistan and France. One can bear its imprints in religious places, old houses of Srinagar. During the later periods of Kashmir history the art remained alive because of the efforts of locals.

\section{Wood Work}

The work seems to have been introduced by Sultan Zainul Abidin. The Muslim worship places are an eloquent proof to the fact that the art really received great stimulus. Some of Shrines of Muslims such as Khanqah-i-Mualla, Khanqahi Naqshband Sahib, Khanqah of Makhdum Sahib and Khanqahi Pir Dastgir are the models of Kashmiri carpentry craft. The specialty of wood work in Kashmir know as Khatamband has been mentioned by Sir Lawrence in these words, "beautiful ceilings of perfect designs, cheap and effective are made by a few carpenters, who with marvelous skill piece together thin slices of pine wood. The result is a charming ceiling in which various shades of the pine slips blend together in perfect harmony ". The wood art during the present era is having the great market value. It seems that old tradition of Wood work is being revived in valley. The industry is having the great potential to fulfill the needs of people at local levels. Efforts should be taken to boost the industry with better facilities, so that more and more people are inclined towards the art, keeping aside the hereditarial traditions.

\section{Kangri Work}

The art of making the Kangri was prevalent in the valley of Kashmir before Sultan Zainul Abidin. But the local workers too were patronized by him and with the passage of time the art progressed too much. The Kangri or Kangar forms an important part of Kashmiri life. The Kangri a portable vessel generally consists of two parts, the inner earthenware bowl of a quaint shape called kundal, in which the fire is placed and its encasement of wicker work, sometimes simple and sometimes very attractive and ornamented with beautiful rings and colours. An attractive wooden or silver spoon called as tsalan is tied to the handle completes this oriental brazier. It also consist of only an earthen vessel known as manan.The best Kangries are mostly made by rural people of, Anantnag, Pulwama, Shopian, Tral, Charar, Sopore etc. The Kangri forms an integral part of Kashmiri culture and even has become a source of income to many people. Importance of Kangri in Kashmir valley can be best judged by the couplet quoted by Mohd Ishaq Khan in History of Srinagar,

"O Kangri :0 Kangri :you are dear to me like a houri and fairy:

When I take you under my arm, you drive away pain from my heart "

During the present era Kangri is still used by the people. The Kangari saves the people from severe cold during the winter especially in the months of December and January.

\section{Music and Musical Instruments}

The school of music was founded in Kashmir by Irani and Turani musicians under the liberal patronage of Sultan Zainul Abidin.As a result of foreign influence many new good melodies incorporated into Kashmiri music.They are,rast, charagah, iraqi, nawa, rahavi, yemen, kalyan, khamaj, bihag, jhinjoti, pahari, bilaval, hussaini,todi, asaoari, tilang, udasi, purbi, sohni, kangra and dhanasri. On account of the Sultans generosity and his love for music many good sazindas (players) and guindas (chanters) flocked to Kashmir from all directions of the world. One such artist was , Mulla Udi, Mulla Jamal from Khurasan and Srivara the author of Zaina Rajatrangini. Among them Mulla Jamal was great expert in vocal music.

Volume 3

Page 5 
The art of Drama was also encouraged by him and also participated in a number of festivals. The Sultan Zainul Abidin encouraged the art of dancing by paying all the dancers liberally and also some of them were employed in the imperial services. With the result people were attracted and influenced and he was so much enamoured with music that whenever he was impressed with any musician, he used to order that his instruments be set with gold and silver. In such circumstances the art spreaded to far off areas of the valley, as is visible today in and around the areas of Srinagar city.

\section{Kashmiri Swords}

From the very beginning the valley artists were known as the best sword manufacturers. Swords were frequently ornamented with figures in relief of man and animals. The figures of sportsmen on foot and on elephants really is unreachable job. Having such a skill the progressive art declined because of non seriousness of authorities. At present the industry exists no more.

\section{Silver and Copperware}

The said art progressed very much under the proper attention of Sultan Zainul Abidin and products of different designs and patterns were manufactured by the local artists of valley. The plain and inlaid silverware of valley is having the great demand. Items of silverware include, tea sets, flower vases, scent chests, ornamental picture frames and cigarette cases. Designs include leaves of chinar and lotus. Besides they also produce copperware items like, cooking pots and Kashmiri Samovar (tea kettle) the rich heritage of valley. At present the items are having the good market especially for the beautiful cooper trays inlet into tables of carved walnut wood. After the death of great king of Kashmir Sultan Zainul Abidin in, 1470.A.D, the art declined and was later on revived by Mirza Haider Dughlat, 1540-51,A.D. He introduced new types of windows and doors in public buildings and improved the architectural designs too.too. Also a new industry known as mat making was introduced by him. Lawrence says Kashmiri "Pech" is the swamp plant from which excellent matting known as" wagu" is made. It was the result of his hard work that in a very short period of time people regained their economic prosperity.

\section{CONCLUSION}

Really the overall condition of people has remained good during the period. Because the continuous struggle of people towards newer industrial modules and designs have completely changed the social structure of Kashmir society. Not only economy of people, but socio-religious and cultural relations also got revived and reformed.With the result whole society was revolutionized internally and externally for positive conduct and approach.

\section{REFERENCES}

1. Bamzai P.N.K, Cultural and political history of Kashmir, Srinagar, vol, ii,2007,pp,153-54.

2. Hassan Mohibul, Kashmir under Sultans, Srinagar, 1959, p.92

3. Kapur M.L,The history and culture of Kashmir, Jammu, 1992, pp.216-217

4. Singh N.K, Islamic heritage of Kashmir, vol.ii, Srinagar, 2000,p.105.

5. Khan Ishaq, History of Srinagar, 1846-1947,Srinagar, 2006, pp, 55,57.

6. Hassan Mohibul, Kashmir under Sultans, Srinagar, 1959, pp.92-93.

7. Bamzai P.N.K, Cultural and political history of Kashmir, Srinagar, vol.ii, 2007, p.34

8. Deambi Kaul B.K, Kashmir and Central Asia, Srinagar, 1989, p.111.

9. Sofi G. M. D, Islamic culture in Kashmir, Srinagar, 2007,257-59.

Volume 3 
American Research Journal of History and Culture (ARJHC)

10. Kapur M.L,The history and culture of Kashmir, Jammu, 1992, pp.217.

11. Lawrence Walter, The valley of Kashmir,Srinagar, 1967,p.380.

12. Hassan Mohibul, Kashmir under Sultans, Srinagar, 1959, p.93.

13. Deambi Kaul B.K, Kashmir and Central Asia, Srinagar, 1989, pp.112-113.

14. Singh N.K, Islamic heritage of Kashmir, Srinagar vol,ii, 2000, p.40.

15. Kapur M.L,The history and culture of Kashmir, Jammu, 1992, pp.217-218.

16. Foaq Mohammad-din, Tarikhi Budshahi, Srinagar, 1928, pp.404-405.

17. Fazl Abul, Ain-i-Akbari, trans, vol, ii, iii, 1989,pp,305-306.

18. Haider Mirza Dughlat, Tarikhi Rashidi, trans , Elias and Ross, 2000,pp,65-66.

Citation: Dr. Syed Damsaz Ali Andrabi, Industrial Development:Socio-Economic Changes in Kashmir Society (1339-1551.A D.)". American Research Journal of History and Culture; Volume 3, 2017; pp:1-7

Copyright (c) 2017 Dr. Syed Damsaz Ali Andrabi. This is an open access article distributed under the Creative Commons Attribution License, which permits unrestricted use, distribution, and reproduction in any medium, provided the original work is properly cited. 